\title{
KEYWORDS
}

\section{The Model Minority}

\author{
Asian American Immigrant Families and Intimate Harm \\ erin Khuê Ninh
}

$\mathrm{n}$ the blinding glow of achievement and hyperfunctionality, it is difficult to discern how the tolls of structural racism and the dehumanizations of capital manifest in the everyday lives of Asian American families. This essay was initially conceived as a response to Lisa Duggan and Tricia Rose's respective work on intimacy and domesticity, work that locates progressive potential where it abides in the day-to-day details of our communities. The conversation was framed in part around the phrase "intimate justice," which served as a reminder that struggles for social justice do not take place in public forums alone, but must indeed have a context in our closest human connections-may indeed emerge from the home. Yet triangulating these scholars' visions for progressive familial formations with my own work on the Asian immigrant family presented a confounding question: Can the family that subscribes not only to Marriage, Military, and the Market but also to itself as Model Minority—can that family be redeemed as a challenge to structural racism? Can the family so eagerly recruited into reminding heteronormativity that it can rise again — can that family be made to imagine justice instead of success?

In progressive race politics it is simply not done to allege that your typical Asian immigrant family would like nothing better than to be the model minority. There is among Asian American leftists a gag order, not unlike the one that Tricia Rose cites in her Afterword to Longing to Tell. There she mentions the historical efforts of "many black intellectuals and social and political leaders... to protect the entire community" from hostile narratives of the Black family. ${ }^{1}$ To do so, they call on Black women to practice a self-censorship that refrains from "sharing experiences [that] might prove racist sociologists right.".

A good portion of the structural comparison we can make here is one to one. Hegemonic constructions of Asian cultures as (more) misogynist, of Asian hus-

erin Khuê Ninh is an associate professor of Asian American studies at the University of California, Santa Barbara, and the author of Ingratitude: The Debt-Bound Daughter in Asian American Literature (New York University Press, 2011).

Kalfou, Volume 1, Issue 2 (Fall 2014). ( 2014 by the Regents of the University of California. ISSN 2151-4712 (print). ISSN 2372-0751 (online). http://dx.doi.org/10.15367/kf.vli2.38. All rights reserved. 
bands and fathers as (more) oppressive, are met with a politically necessary and concerted disavowal. But smothered in the blanket disavowal is the stubborn remainder; even if our ethnic communities are not "more" misogynist, they are not less. Tending to the wounds of patriarchal masculinities is "race work" common, then, to women in both Black and Asian American communities: a shared "consensus issue."

Among Asian American academics, however, the gag order extends also to a familial politics in excess of gender. We train our students to retort that the model minority is a figment of the white imagination. We tell them statistics lie; Asians are not doing nearly so well; look after all at the Southeast Asians, they are in gangs. But it is a red herring and, moreover, a disingenuous case to make. The heart of the issue is not whether Asian immigrant families currently meet the measures of the model minority; the issue is whether they aspire to, whether they apply those metrics. And they do. The racial ideologies, the economic infrastructures, the educational paradigms of Asianness do not circle the immigrant home like vampires, held at bay by bulbs of garlic; they are invited in to dine, made part of the nuclear family. Which is to say that the immigrant nuclear family is not only busy grappling with, fending off, and challenging certain structural racisms; it is also busily reinforcing, perpetuating, and living up to certain other aspects of racist structures. Despite Asian American socialmovement investments in seeing the immigrant family as a resistant space, this has not so much enabled the practice of intimate justice as it has required the disregard of intimate harm.

I believe that our artists and writers have been proffering correctives to our political fictions for some time. Maxine Hong Kingston's Fa Mu Lan fantasies in The Woman Warrior are eloquent about her needs both to protect the ethnic family and to protect herself from the ethnic family. When urban renewal tears down her parents' laundry, she dreams of avenging them against the businesssuited enemy. "It's not just the stupid racists that I have to do something about," she says, "but the tyrants who for whatever reason can deny my family food and work." In Kingston's second book, it is the abuse heaped upon Maxine's father at the laundry that he heaps in turn upon his children. What Tricia Rose refers to as "the interior, intimate impact of structural racism" does indeed find us where we live. ${ }^{5}$ This politically conditioned love behind Maxine's longing for social justice does not, however, change the fact that "when [she] visit[s] the family now," she must wrap her "American successes around [her] like a private shawl"-a statement that attests to a sense that she needs psychological protection in order to go home, that she feels profoundly unsafe there. ${ }^{6}$

In other words, a politically conditioned love may hope to protect Maxine's family against the racist hate they resist, but can it be retooled to protect her against the "racist love" her family accepts? What form can interpersonal justice take, tasked with reframing not dysfunction but hyperfunctionality, with not 
pathology but model heteronormative health? I borrow here terms from Frank Chin and company's early articulations of Asian American identity politics, to ask what it may be safe or left to love, if love is in fact the way that power operates. It is with racist love, sexist love, and even capitalist love that the Asian American is wooed into representing, as Lisa Duggan says, "hegemonic formations of the political economy-even as they are excluded from full participation and political representation."7 The title of a self-help book written by secondgeneration Korean American sisters Soo and Jane Kim says it all: Top of the Class: How Asian Parents Raise High Achievers-and How You Can Too. It is to the Asian immigrant family that the white mainstream looks, as if for a vaccine to halt the anxious decline of the white nuclear family. What does this vehicle for proper, private social reproduction produce but an avatar of the proper, capitalist subject with high earning power and high disposable income?

Aihwa Ong and Christine So remind us that legal citizenship, or even economic citizenship, is not the same as social equality. The financial value of Asian Americans is not a currency they can exchange for the cultural citizenship that denotes social belonging and inclusion; their money is no good here. But as Duggan argues about homonormativity, even the desire for inclusion is corrosive. Having been so nearly recruited into conservative forms, Asian American desire is likewise rechanneled, in ways that disable justice, love, freedom, revolution-leaving only success.

Is a kind of interpersonal justice possible in such a context? I would hope so, because I could not agree more that the structural causes of injustice concern the normal and ongoing, and so must be challenged and negotiated in the intimate spheres, in the everyday. ${ }^{8}$ Yet what that transformative move would be is not so apparent from here. It must be allowed, however, to look something different from the love that combats racist hate. For all the structural parallels between Black and Asian racial forms, these racial projects are not analogies but mirrored images. As we know well, that opposition is not accidental. For that reason, we must not fail to recognize that what is progressive in one context can be regressive in the other; we cannot expect resistance to take identical bearings in inverted contexts and not backfire.

I suspect that for Asian Americans, no transformation of intimate oppressions can come from the Mama Younger narrative that Lorraine Hansberry advances in A Raisin in the Sun and that Rose uses to theorize the nature of interpersonal justice. ${ }^{9}$ As one that centers the parent-child relation, the narrative Mama personifies as an African American hope for healing is the very same narrative that, for the immigrant's child, justifies continuing injury. The hyperheteronormativity of the model minority family does not rest on marriage; as the Kim sisters advise, "Single parents, you too can adopt these child-rearing practices!" The relation that constitutes its normativity, its productivity, and hopefully its replicatability-is the intergenerational. The DNA that makes it (re)productive 
is the code of sacrifice: "It is [Mama]," in Hansberry's play, "who ... scrubs the floors of the nation in order to create black diplomats and university professors"; ${ }^{10}$ swap out a few words in that description-Asian for Black, "doctors" for "diplomats," and "lawyers" for "university professors" - and we arrive at the classic trope of the self-sacrificing immigrant parent.

Here, triangulating the Asian American into these black/white models of the normative and non-normative family wreaks havoc for progressive politics (and this is, not coincidentally, quite the function of the model minority: to wreak havoc for progressive politics). Because while Duggan locates the "symbolic linchpin of the household" in marriage ${ }^{11}$-and thus the downfall of homonormativity in its co-opted desire for that legal sanction-I wonder whether she allows an implicit opposition between the conservatism of formal marriage and the familial function of caretaking. If so, this suggests an oppositional promise to "intimate caretaking" for the "young, aged, and infirm," such that if challenges to the material reproductive order were to emerge from somewhere, such relations as parenting "in the face of inequality and deprivation" might be the likely source. ${ }^{12}$ This model would be in keeping with the premises of interpersonal justice. As Rose quotes Hansberry saying of Mama, "Seemingly clinging to traditional restraints, it is she who drives the young into fire hoses" for social change..$^{13}$

What the Asian immigrant family does, however, is to demonstrate that intimate caretaking in the face of inequality and deprivation can be the most hypernormative, neoliberal act of all. The story of the self-sacrificing immigrant parent is actually a variety of the culturally pervasive narrative we know as "for the sake of the Child"-and here I return to Duggan's troubling of Lee Edelman's No Future. ${ }^{14}$ Certainly it would be inaccurate to essentialize queerness as the position outside the reproductive order, as Edelman may seem to, and dangerous to romanticize the rather privileged position of being without caretaking duties. With these warnings firmly in mind, however, I'd like to rehabilitate for us here his essential point about the ideological coerciveness of this figural Child, this reproductive futurism. As Edelman writes, "The social order exists to preserve for this universalized subject, this fantasmatic Child, a notional freedom more highly valued than the actuality of freedom itself." 15 To be opposed to the future in the form of that emblematic Child is unthinkable, politically unsanctionable. And so we are all to sacrifice for the health, wealth, and enfranchisement of that Child- "though," he writes, "always at the cost of limiting the rights 'real' citizens," and any historical children, "are allowed." ${ }^{16}$ As a symbolic linchpin for ideological agendas, then, the Child is a heavyweightbut the Child is also a fiction, a rhetorical begging of the question such that the only possible political response is compliance.

The narrative of the parent who sacrifices for the sake of the Child is thus an intimately coercive one. In the name of the figural Asian American Child, 
the historical, actual child must surrender rights; the model minority Future, after all, must not be endangered by present-day freedoms. The narrative of parent-child sacrifices is a teleological one, purposive and directed toward that future result. "Love" becomes instrumental, because the reproductive family is a cottage industry and the successful "Child" its product.

There are correctives to be found in Asian American literature to the fantasy of the Child and the sacrificial parent, as well. The easiest to cite is Evelyn Lau's Runaway - a diary Lau kept when at the age of fourteen she left home and spent two years on the street in Canada-where one would expect Maslow's hierarchy of needs to revert to the basics of shelter and food. She flees from her hardworking, self-sacrificial, racially marginalized and economically deprived parents-who want no more from her than her future as a cardiologist or corporate lawyer. But rather than surrender on demand all else she might imagine to that false idol of herself, Lau permanently refuses that future: the future for her sake. While such a refusal is not yet an act of interpersonal justice, it may well be the moment immediately prior, when the subject can no longer be raised to embrace modernity's narratives of success. If Lau is any indication, then the oppositional position that negates normative sociality is not inherently queer; rather, it is a strategic one, in which the subject finds that the disciplinary image of the Child may be loving yet not benign. Such a subject, finding that the socioeconomically ambitious "future is mere repetition and just as lethal as the past," 17 is "queer" only in the sense that Edelman specifies: queerness as naming "the side of those "not fighting for the children" - of those who "insist that the future stop here." 18

\section{NOTES}

1. Rose, Longing to Tell, 391.

2. Ibid., 392.

3. Ibid., 391, 27.

4. Kingston, Woman Warrior, 49.

5. Rose, "Domesticity, Intimacy, Affect."

6. Kingston, Woman Warrior, 52.

7. Duggan, "Domesticity and Normativity."

8. Rose, "Envisioning Intimate Justice."

9. Rose, "Hansberry's A Raisin in the Sun."

10. Rose, "Domesticity, Intimacy, Affect."

11. Duggan, "Domesticity, Intimacy, Affect."

12. Duggan, "Domesticity and Normativity," 8, 4, 8 .

13. Rose, "Domesticity, Intimacy, Affect."

14. Duggan, "Domesticity, Intimacy, Affect."

15. Edelman, No Future, 11.

16. Ibid.

17. Edelman, No Future, 31.

18. Ibid., 3, 31. 


\section{BIBLIOGRAPHY}

Chin, Frank, Jeffrey Paul Chan, Lawson Fusao Inada, and Shawn Wong, eds. Aiiieeeee! An Anthology of Asian-American Writers. Washington, DC: Howard University Press, 1974.

Duggan, Lisa. "Domesticity and Normativity: Queer Desire and Neoliberal Rule." University of California, Santa Barbara, presentation, October 24, 2008.

Edelman, Lee. No Future: Queer Theory and the Death Drive. Durham, NC: Duke University Press, 2004.

Kim, Jane, and Soo Kim Abboud. Top of the Class: How Asian Parents Raise High Achieversand How You Can Too. New York: Penguin Group, 2005.

Kingston, Maxine. Chinamen. New York: Knopf, 1980.

. The Woman Warrior: Memoir of a Girlhood among Ghosts. New York: Knopf, 1976.

Lau, Evelyn. Runaway: Diary of a Street Kid. Toronto: Coach House, 1995.

Ong, Aihwa. Flexible Citizenship: The Cultural Logics of Transnationality. Durham, NC: Duke University Press, 1999.

Rose, Tricia. "Envisioning Intimate Justice in African-American Culture and Politics." University of California, Santa Barbara, presentation, October 24, 2008.

- "Hansberry's A Raisin in the Sun and the 'Illegible' Politics of (Inter)personal Justice." Kalfou 1, no. 1 (2014): 27-60.

- Longing to Tell. New York: Farrar, Straus, and Giroux, 2003.

So, Christine. Economic Citizens: A Narrative of Asian American Visibility. Philadelphia: Temple University Press, 2007. 